\title{
Numerical Study on the Massive Outbreak of the Ulva prolifera Green Tides in the Southwestern Yellow Sea in 2021
}

\author{
Bin Wang 1,2,*(D) and Lei Wu ${ }^{1,2}$ \\ 1 Key Laboratory of Marine Hazards Forecasting, Ministry of Natural Resources, Hohai University, \\ Nanjing 210098, China; wl7@hhu.edu.cn \\ 2 College of Oceanography, Hohai University, Nanjing 210098, China \\ * Correspondence: 20160018@hhu.edu.cn
}

check for updates

Citation: Wang, B.; Wu, L. Numerical Study on the Massive Outbreak of the Ulva prolifera Green Tides in the Southwestern Yellow Sea in 2021. J. Mar. Sci. Eng. 2021, 9, 1167. https:// doi.org/10.3390/jmse9111167

Academic Editors: Zhun Li and Bum Soo Park

Received: 28 September 2021

Accepted: 22 October 2021

Published: 24 October 2021

Publisher's Note: MDPI stays neutral with regard to jurisdictional claims in published maps and institutional affiliations.

Copyright: (c) 2021 by the authors. Licensee MDPI, Basel, Switzerland. This article is an open access article distributed under the terms and conditions of the Creative Commons Attribution (CC BY) license (https:// creativecommons.org/licenses/by/ $4.0 /)$.

\begin{abstract}
The most massive outbreak on record of the Ulva prolifera green tides in the southwestern Yellow Sea occurred in summer of 2021. The environmental factors were investigated based on observations and simulations. The results suggested that the significantly enhanced discharge of the Changjiang River since winter 2020-2021 was crucial for the outbreak of the Ulva prolifera green tides in the southwestern Yellow Sea, which could significantly have contributed to the nutrient enrichment off the Subei coast. Additionally, the southerly wind stress anomaly during winter 2020-2021 favored the upwind transport of Changjiang water. Numerical experiments showed that the remaining winter freshwater coming from the Changjiang River, which persisted in the Subei coast's upper layer until spring 2021, exceeded the long-term average value by $20 \%$. We demonstrated that these large amount of nutrient inputs, as an effective supplement, were the reason the green tides sharply emerged as an extensive outbreak in 2021. The easterly wind anomaly during spring 2021 contributed to the landing of Ulva prolifera off the Lunan coast.
\end{abstract}

Keywords: Ulva prolifera; Changjiang; southwestern Yellow Sea; outbreak mechanisms; wind anomaly

\section{Introduction}

The Yellow Sea, surrounded by Mainland China and the Korean Peninsula, is a characteristic continental shelf sea (Figure 1). It plays an important role in the environment of China and the Korean Peninsula. The bathymetry of the Yellow Sea is generally shallow and complex. The southwestern Yellow Sea is listed as a marginal sea with various contributions from land, rivers, and tides, which has been the focus of multi-disciplinary research in recent years.

Over the past 15 years (from 2007 to 2021), successively occurrences of Ulva prolifera green tides have become a striking recurrent phenomenon in the southwestern Yellow Sea. The average distribution area and the cover area were reported to be $37,000 \mathrm{~km}^{2}$ and $450 \mathrm{~km}^{2}$, respectively, in recent ten years. The general consensus is that the green tide originates from the coast of Subei in late spring. It migrates northward with the ocean current [1-3] and lands on the Lunan coast over long-distance migration every summer. The Ulva prolifera green tides have had detrimental effects on the local marine environment and ecosystem [4]. According to the previous studies, Ulva prolifera has wide adaptability to temperature and salinity [5-7]. The freshwater from the Changjiang River and local rivers provide abundant nutrients into the southwestern Yellow Sea and is also suitable for the growth of Ulva prolifera. Dissolved inorganic nitrogen (DIN) has been suggested to play a crucial role in the bloom of Ulva prolifera [8-11]. Chen et al. [12] found that the nutrient distribution and structure in the Jiangsu coast was affected by the land-based load, and the ratio of nitrogen to phosphorus could affect the bloom of Ulva prolifera significantly. Wang et al. [13] suggested the phosphate limitation on the initial growth of Ulva prolifera seedling can occur in the southern Yellow Sea. Later, Sun et al. [14] confirmed that the DIN was the most critical nutrient controlling the magnitude and time of the green tide rather 
than phosphorus, based on a dynamic growth model. According to the observations, the DIN concentration in the southwestern Yellow Sea is lowest in the winter and reaches its highest value in April [7,11,15], which implies that overwintering banks of nutrients might be an important population trigger of Ulva prolifera $[16,17]$.

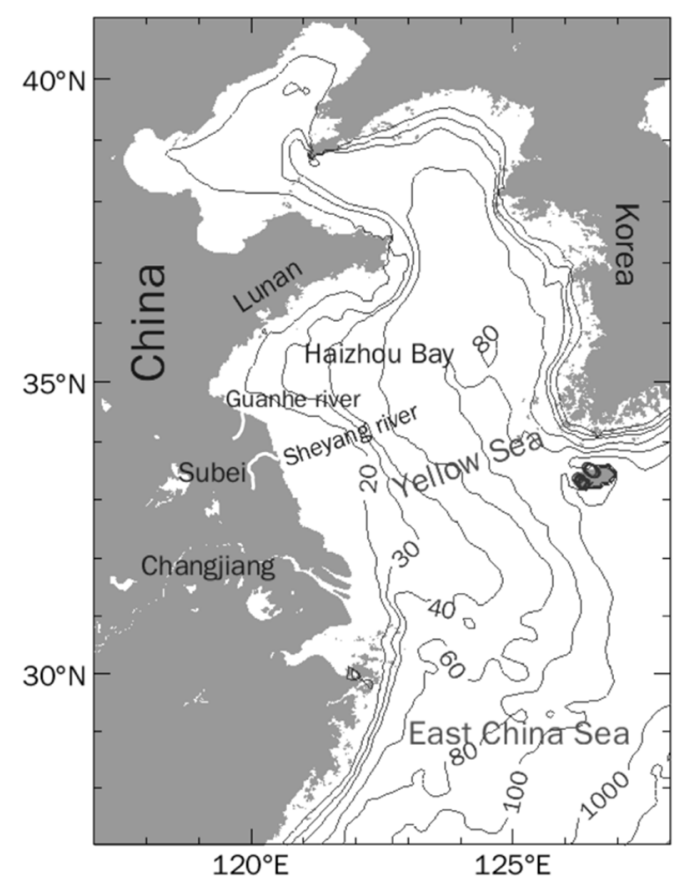

Figure 1. Model domain with geography and bathymetry (unit: $\mathrm{m}$ ).

However, effective solutions for preventing the harmful algal bloom have not been found so far $[17,18]$. According to the local news, the worst Ulva prolifera green tides in last 15 years occurred in the summer of 2021. The maximal distribution area and the maximal cover area have been over $60,000 \mathrm{~km}^{2}$ and $1700 \mathrm{~km}^{2}$, respectively. The amount of the Ulva prolifera was about 2.3 times that of 2013, which was reported to be the worst year previously.

Thus, based on observational data and numerical modelling, the hydrographical features of the southwestern Yellow Sea from the winter 2020-2021 to summer 2021 were compared with the long-term averaged status. Section 2 comprises a description of the methodology and data used in this study. Section 3 addresses the model results about the inter-annual variation of the green tides. Section 4 is a summary of the study.

\section{Data and Methodology}

\subsection{Observation Data}

The water depth in the nearshore region of Subei is quite shallow, and the observation data are relatively scarce. Supported by the Project on Coastal Investigation and Research (i.e., Project 908) of China, four cruises in four seasons were conducted during 2006 and 2007, mostly covering the Subei coast region. The measured salinity data were reported by Zhang et al. [19]. The digitalized isohaline was compared with the simulated sea surface salinity.

Merged satellite and in situ global daily sea surface temperatures (MGDSSTs) of the Japan Meteorological Agency, with a resolution of $0.25^{\circ} \times 0.25^{\circ}$, were used to validate the simulated sea surface temperatures of the present model.

Furthermore, in late April of 2021, four GPS-tracked ARGOS surface floats were deployed in the southwestern Yellow Sea to measure the currents off the Subei coast. The floats were released along the edge of the Subei Bank to track the movement of the Subei 
coastal current. The trajectories of four surface ARGOS drifters were used to check the simulated circulation.

\subsection{Numerical Modeling}

Based on the Princeton Ocean Model (POM), we established a high-resolution regional circulation model over the Bohai Sea, the Yellow Sea, and a part of the East China Sea. The model, with a horizontal resolution of $1 / 12^{\circ} \times 1 / 12^{\circ}$, covered (Figure 1) the domain of $27^{\circ} \mathrm{N}-41^{\circ} \mathrm{N}, 117^{\circ} \mathrm{E}-128^{\circ} \mathrm{E}$. The vertical sigma coordinates were layered in the following proportions from top to bottom: $0.000,-0.003,-0.006,-0.013,-0.025$, $-0.050,-0.100,-0.200,-0.300,-0.400,-0.500,-0.600,-0.700,-0.800,-0.900$, and -1.00. The model topography was based on the $1^{\prime} \times 1^{\prime}$ Shuttle Radar Topography Mission (SRTM) database. The minimum and maximum depths in this model were set to $10 \mathrm{~m}$ and $4000 \mathrm{~m}$, respectively.

The boundary conditions were determined by the simulated results of a $1 / 12^{\circ} \times 1 / 15^{\circ}$ Eastern Asian Marginal Seas data assimilation model [20]. The monthly mean results from 2001 to 2020 were averaged as the climatological open boundary of the present study. The eight main tidal components $\left(\mathrm{M}_{2}, \mathrm{~S}_{2}, \mathrm{~K}_{1}, \mathrm{O}_{1}, \mathrm{~N}_{2}, \mathrm{P}_{1}, \mathrm{~K}_{2}\right.$, and $\left.\mathrm{Q}_{1}\right)$ also were considered from the open boundary. The tidal harmonic constants were decided by the results of the NAO.99b model [21].

The surface wind stress was determined by the monthly forcing of the ERA5 dataset with a high horizontal resolution of $0.25^{\circ} \times 0.25^{\circ}$. The long-term averaged values were calculated during the same 20-year period described in the previous paragraph as the climatological forcings. The surface heat flux was calculated using a bulk formula [22]. The net heat flux was expressed as the sum of shortwave radiation, longwave radiation, sensible heat flux, and latent heat flux, and all of these components followed the empirical formulas of Hirose et al. [20]. The penetration of the shortwave radiation was also considered, and the water quality was type II [23].

The freshwater flux was estimated with the precipitation $(\mathrm{P})$ and evaporation $(\mathrm{E})$ as well as the river runoffs $(\mathrm{R})$, as $\mathrm{P}+\mathrm{R}-\mathrm{E}$. Precipitation $(\mathrm{P})$ data were also obtained from the long-term averaged monthly ERA5 dataset. The corresponding evaporation (E) was obtained when calculating the latent heat flux as mentioned above. The amounts of the freshwater from Changjiang River were retrieved from the climatological monthly transports at Datong station, which are reported by the Chinese River Sediment Bulletin. The multi-year mean discharges from Subei local rivers were retrieved from the Jiangsu Province Water Resources Bulletin, which are represented by the Guanhe River and the Sheyang River in this study [24]. The discharges of the Guanhe River and Sheyang River and their seasonal variations were also allotted based on the work of Yang [24]. There were no other relaxations for temperature and salinity in the present model.

The model was first integrated with the climatological fields for 4 years. An additional two-year calculation was conducted due to the overwinter effects, using the above last month's status for the restart conditions. The experiment that used the climatological meteorological forcings and boundary conditions was named Exp.C (referring to climatological meteorological forcings). To investigate the environmental features in the winter 2020-2012, a comparative experiment was designed (Table 1). The realistic monthly meteorological forcings and boundary conditions were employed and named Exp.R (referring to realistic forcings). Exp.R was established under the daily meteorological forcings from January 2020 to June 2021, and the Changjiang River discharges were also changed to the realistic monthly discharges. The values and their comparisons to meteorological values during the interested period are listed in Table 2. 
Table 1. List of experiments.

\begin{tabular}{ccc}
\hline Experiments & Discharges & Forcings and Boundary Conditions \\
\hline Exp.C & $\begin{array}{r}\text { Climatological monthly discharges of Changiang } \\
\text { River and Subei local rivers } \\
\text { Realistic monthly discharge of Changiang River } \\
\text { and climatological discharge of Subei local rivers }\end{array}$ & $\begin{array}{c}\text { Climatological meteorological forcings and } \\
\text { boundary conditions }\end{array}$ \\
Exp.R & $\begin{array}{c}\text { Realistic daily meteorological forcings and } \\
\text { boundary conditions }\end{array}$ \\
\hline
\end{tabular}

Table 2. Changiiang discharges $\left(10^{8} \mathrm{~m}^{3}\right)$.

\begin{tabular}{cccccccc}
\hline Time & $\begin{array}{c}\text { December } \\
\mathbf{2 0 2 0}\end{array}$ & $\begin{array}{c}\text { January } \\
\mathbf{2 0 2 1}\end{array}$ & $\begin{array}{c}\text { February } \\
\mathbf{2 0 2 1}\end{array}$ & $\begin{array}{c}\text { March } \\
\mathbf{2 0 2 1}\end{array}$ & April 2021 & May 2021 & June 2021 \\
\hline $\begin{array}{c}\text { Monthly Changjiang } \\
\text { discharge (related to } \\
\text { meteorological values) }\end{array}$ & $\begin{array}{c}436.6 \\
(+10.5 \%)\end{array}$ & $\begin{array}{c}407.1 \\
(+31.4 \%)\end{array}$ & $\begin{array}{c}326.6 \\
(+9.3 \%)\end{array}$ & $\begin{array}{c}530.3 \\
(+16.9 \%)\end{array}$ & $\begin{array}{c}686.9 \\
(+10.7 \%)\end{array}$ & $\begin{array}{c}1122 \\
(+24.6 \%)\end{array}$ & $\begin{array}{c}1216 \\
(+15.8 \%)\end{array}$ \\
\hline
\end{tabular}

\subsection{Passive Tracer}

Salinity distribution can present the pathway of the Changjiang River qualitatively. To quantitatively discuss the roles of the Changjiang River discharges, the passive tracer was continuously released in the numerical experiments from December to the following June at the Changiiang River estuary. The initial value of the passive tracer was 0 , which means the nutrient content from the Changiiang River was 0 at the beginning. The tracer concentration at the estuary was set to 1 , which was dimensionless and represented the nutrient concentrations inputted from the Changjiang River. According to Zhang et al. [11], the area south of $35^{\circ} \mathrm{N}$ and west of $122^{\circ} \mathrm{E}$ is one in which the Ulva prolifera was rapidly developed. Therefore, the persisted tracer content in the upper layer (within $5 \mathrm{~m}$ depth) of the region $32-35^{\circ} \mathrm{N}, 119-122^{\circ} \mathrm{E}$ was also calculated, following Formula (1):

$$
T_{c}=\int c d v
$$

where $T_{c}$ is the content of tracer in the upper layer, and $c$ is the tracer's concentration.

\section{Results}

\subsection{Model Validations}

The simulated sea surface temperatures (SSTs) in Exp.C were compared with MGDSSTs. The basic features of the SST in summer and winter were well-represented (Figure 2). Our model successfully reproduced the surface cold patch off the Subei coast in the summer and the intrusion of the high temperature water in the winter. There were slightly larger differences in the nearshore region (shallower than $10 \mathrm{~m}$ ) between the simulated SST and MGDSSTs. This may have been due to the lower horizontal resolution of MGDSSTs. Furthermore, shown in Figure 3, the root-mean-square errors between simulated SST and MGDSSTs were $0.99{ }^{\circ} \mathrm{C}$ in the summer and $1.15^{\circ} \mathrm{C}$ in the winter after interpolating the MGDSSTS to the model grids.

The digitalized isohalines in the southwestern Yellow Sea in each seasons were overlaid on the simulated results of Exp.C (Figure 4). It should be noted that the digitalized isohalines were based on observations during a particular period. The simulated salinities represent the climatological distributions. Therefore, more attention should be paid to the pattern of simulated isohalines instead of the reproduction of isolated low-salinity water patches. The low-salinity water (<30 PSU) of Changiiang diluted water occupies most of the southwest Yellow and East China Seas in the summer (Figure 4c). Though with a significantly reduced range, it retreats to the coast with large horizontal gradients in other seasons. The 30 and 31 PSU isohalines in individual seasons were also found to be in good agreement with observations. All the characteristics, including the seasonal evolutions 
of the isohalines (Figure 4a-d), were well-simulated by Exp.C, implying that the present model is able to capture the essential mass transportations in this area.
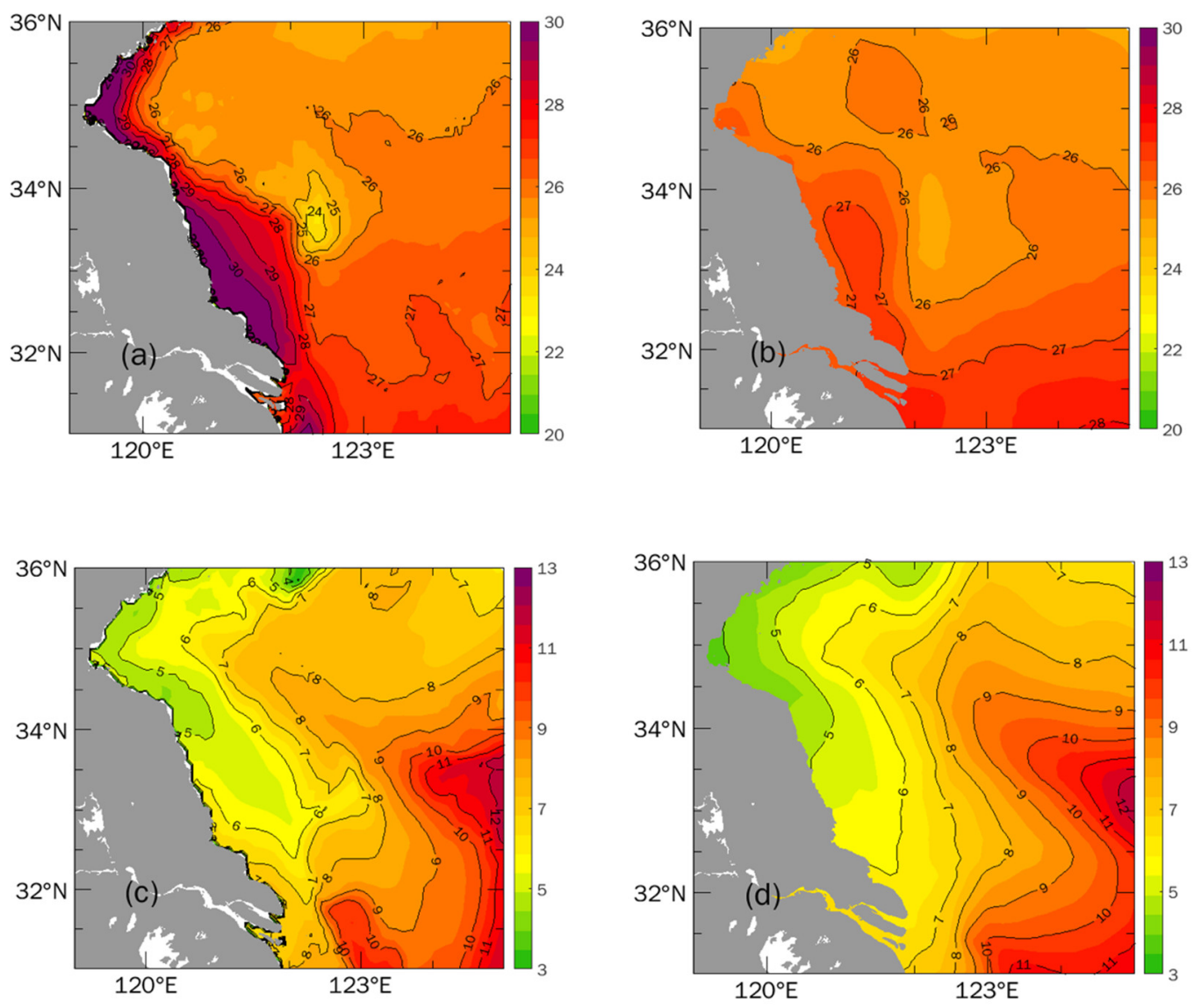

Figure 2. Simulated summer sea surface temperature of (a) Exp.C and (b) MGDSSTs; simulated winter sea surface temperature of (c) Exp.C and (d) MGDSSTs (unit: ${ }^{\circ} \mathrm{C}$ ).

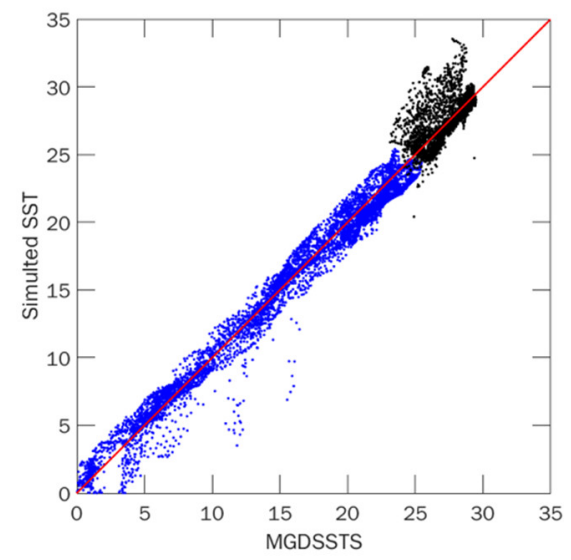

Figure 3. Validations of simulated surface temperature with MGDSSTs. Black and blue dots represent summer and winter values, respectively (unit: ${ }^{\circ} \mathrm{C}$ ).

Four ARGOS surface drifts (Figure 5a) were deployed off the Subei coast since late April of 2021. For comparison, in the realistic case of Exp.R, eleven modeled drifters (Figure $5 \mathrm{~b}$ ) were released at the sea surface. The initial locations of the simulated drifters followed those of the ARGOS drifts. Simulated circulation was represented by the pathway of the modeled surface drifters. The trajectories of the modeled drifters, which were deemed to be Lagrangian particles, were calculated by the fourthorder Runge-Kutta scheme [25]. The positions of the drifters were calculated every 
3 computational hours until end of June 2021. Figure 5 suggests that the pattern of the modeled drifter trajectories successfully reproduced the observed ones of ARGOS surface drifters. The characteristics of the ARGOS trajectories were well-simulated by this experiment, once again showing that the present model can capture the realistic features of regional circulation.
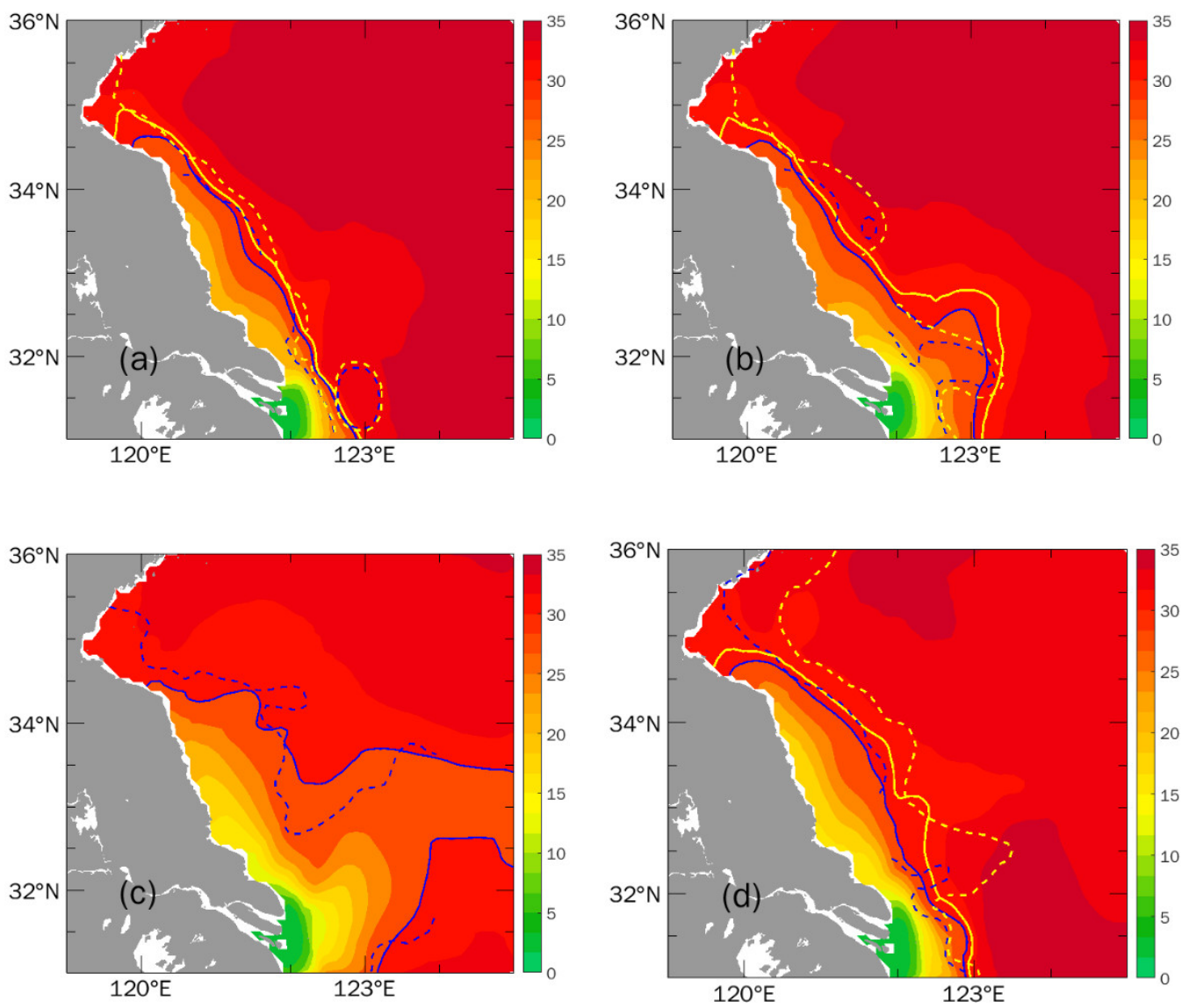

Figure 4. Simulated climatological salinity at $10 \mathrm{~m}$ of Exp.C in (a) winter, (b) spring, (c) summer, and (d) autumn (unit: PSU). The solid line is the simulated isohaline, and the dashed line is the observed isohaline digitalized from the work of Zhang et al. [19]. The blue and yellow lines represent the 30 and 31 PSU, respectively.
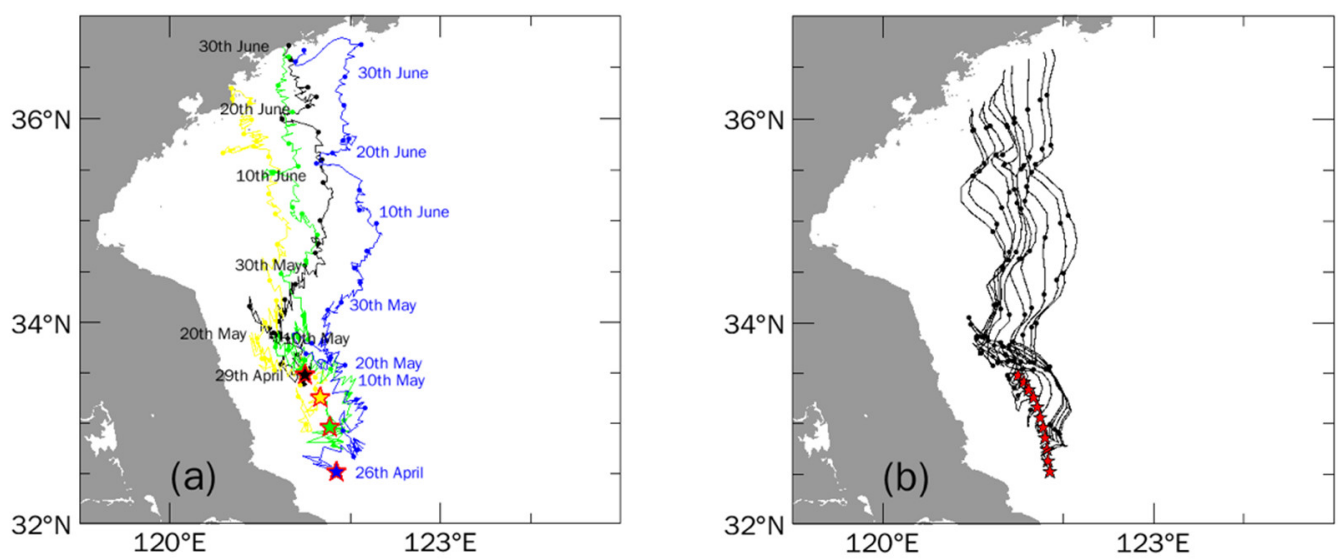

Figure 5. Observed (a) and simulated (b) trajectories of surface ARGOS drifters released in late April 2021 off the Subei coast. Star markers represent the released locations. 


\subsection{Hydrography in the Summer of 2021}

The simulated tracer distributions at the surface until late April are shown in Figure 6. In Exp.C, a part of the Changjiang River water drifted northward, which could reach $33^{\circ} \mathrm{N}$ in late April. A relative high concentration surface patch was identified off the Subei coast (Figure 6a), which was reported as the first observed region of Ulva prolifera in several years (Bulletin of China Marine Disaster). In the meantime, as listed in Table 2, the discharges of the Changjiang River were significantly increased since late 2020 compared with the climatological ones. Correspondingly, the simulated tracer concentration in Exp.R showed a large positive anomaly distribution along the Subei coast. In other words, the larger Changjiang River input in the winter 2020-2021 and spring of 2021 significantly contributed to the nutrient enrichment off the Subei coast, which led to the most massive outbreak of the Ulva prolifera green tides in the southwestern Yellow Sea the in summer of 2021.
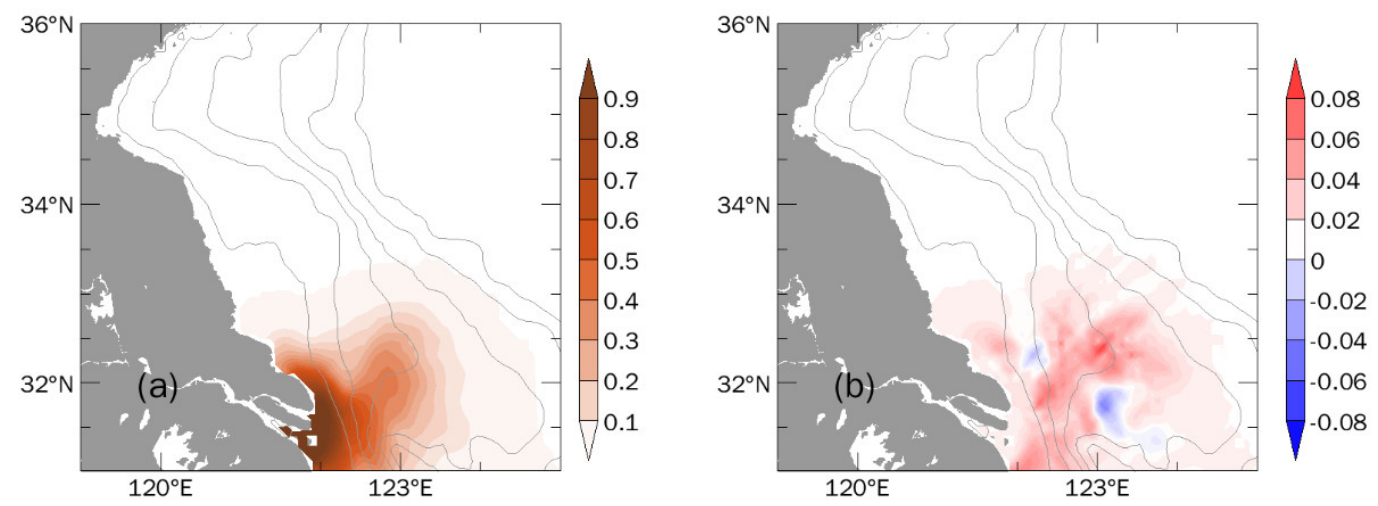

Figure 6. Simulated distribution of the passive tracer (a) in Exp.C and (b) anomaly distribution in Exp.R at the sea surface in late April with the bathymetry.

The tracer content results showed that in late April, $T_{\mathcal{C}}$ was found to be $1.20 \times 10^{10} \mathrm{~m}^{3}$ in Exp.C, which was almost $5 \%$ of the total Changiiang input, while in Exp.R, $T_{c}$ approached $1.56 \times 10^{10} \mathrm{~m}^{3}$ in late April, which was more than $6 \%$ of the total Changjiang input during this month. The northward transportation proportion of Changiiang water also was increased. Thus, we checked the wind distribution in the winter of 2020-2021 (Figure 7). In the winter of 2020-2021, the southerly anomaly led to a much weaker north-south component of wind (Figure $7 \mathrm{~b}$ ). Thus, the weakened southward wind-driven current was at a disadvantage in competition with the northward tidal residual current $[26,27]$. The counter-wind transport caused by the northward tidal residual current was dominant during this winter. Thus, there was more remaining winter freshwater from Changiiang at the Subei coast in the spring 2021. Compared with the climatological status, it increased by about $30 \%$.

Until June, the remaining tracer content from the Chanjiang River was found to be significantly increased (Figure 8a) compared to that at the end of April, which provided necessary nutrient supplements for the population of Ulva prolifera. The passive tracer concentration in early summer of 2021 presented a stronger positive anomaly related to the long-term averaged case (Figure $8 \mathrm{~b}$ ). Without considering the biological absorption process, the passive tracer content results suggested that until late June, $T_{\mathcal{c}}$ was $4.79 \times 10^{10} \mathrm{~m}^{3}$ and $5.21 \times 10^{10} \mathrm{~m}^{3}$ for Exp.C and Exp.R, respectively.

The climatological wind during spring over the southwest Yellow Sea distributed northwestward (Figure 9a). It can be seen that there was a clear easterly wind anomaly during spring of 2021 (Figure 9b). The enhanced westward wind component contributed to the shoreward transport of Ulva prolifera, which led to its landing along the Lunan coast over long-distance migration. 

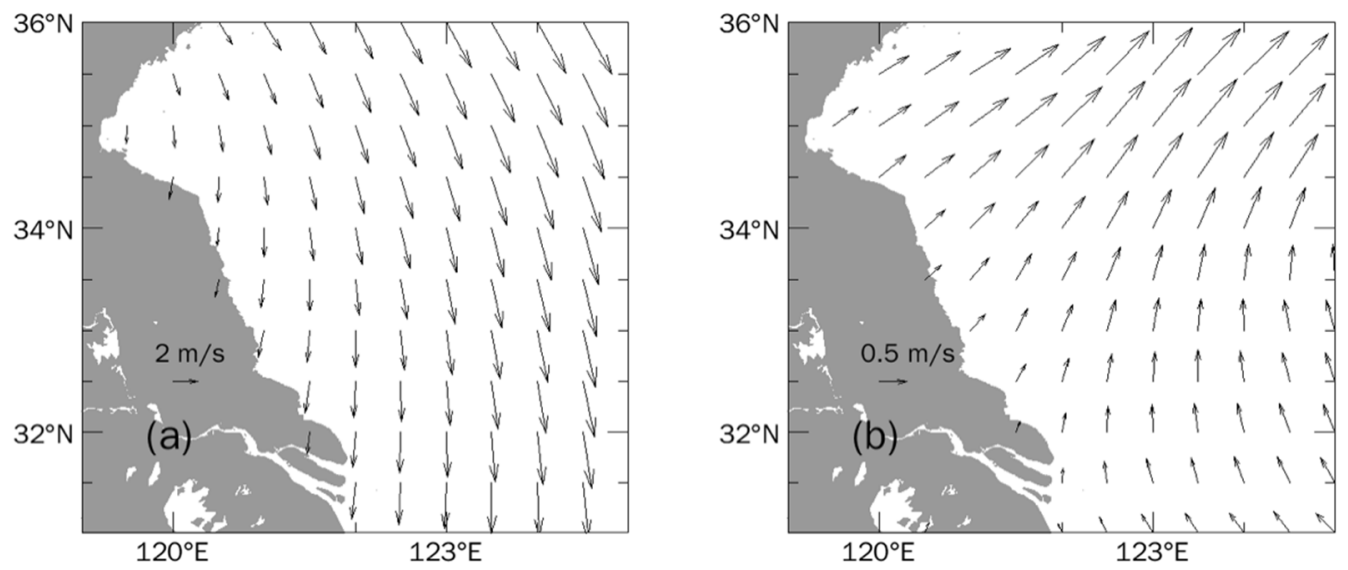

Figure 7. (a) Climatological winter wind distribution and (b) wind anomaly in the winter of 2020-2021 at $10 \mathrm{~m}$ above the southwestern Yellow Sea.
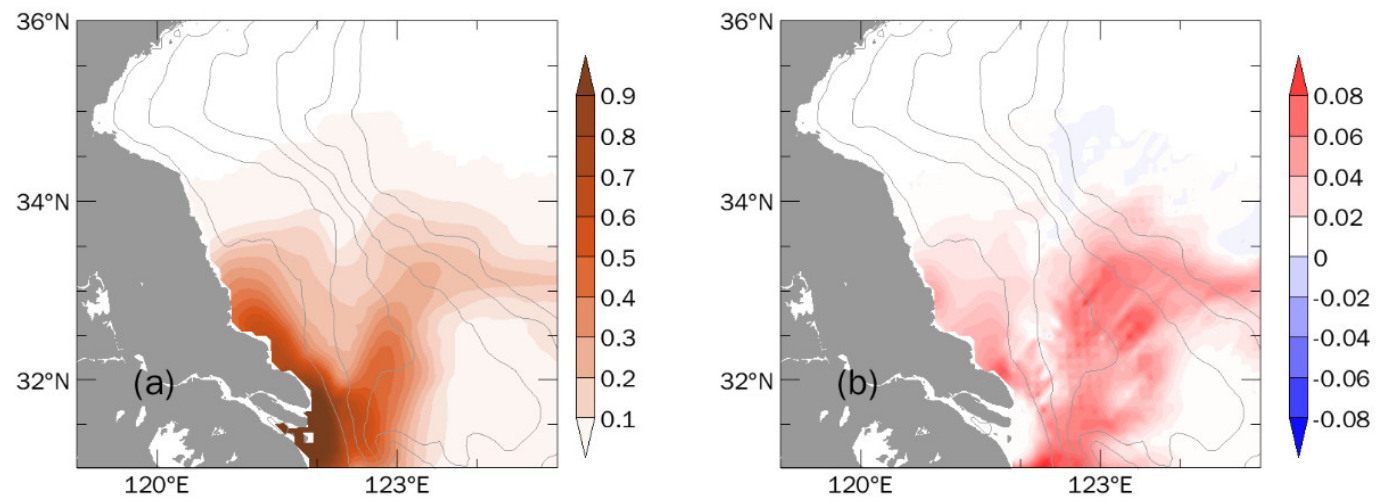

Figure 8. Simulated distribution of the passive tracer (a) in Exp.C and (b) anomaly distribution in Exp.R at the sea surface in late June with the bathymetry.
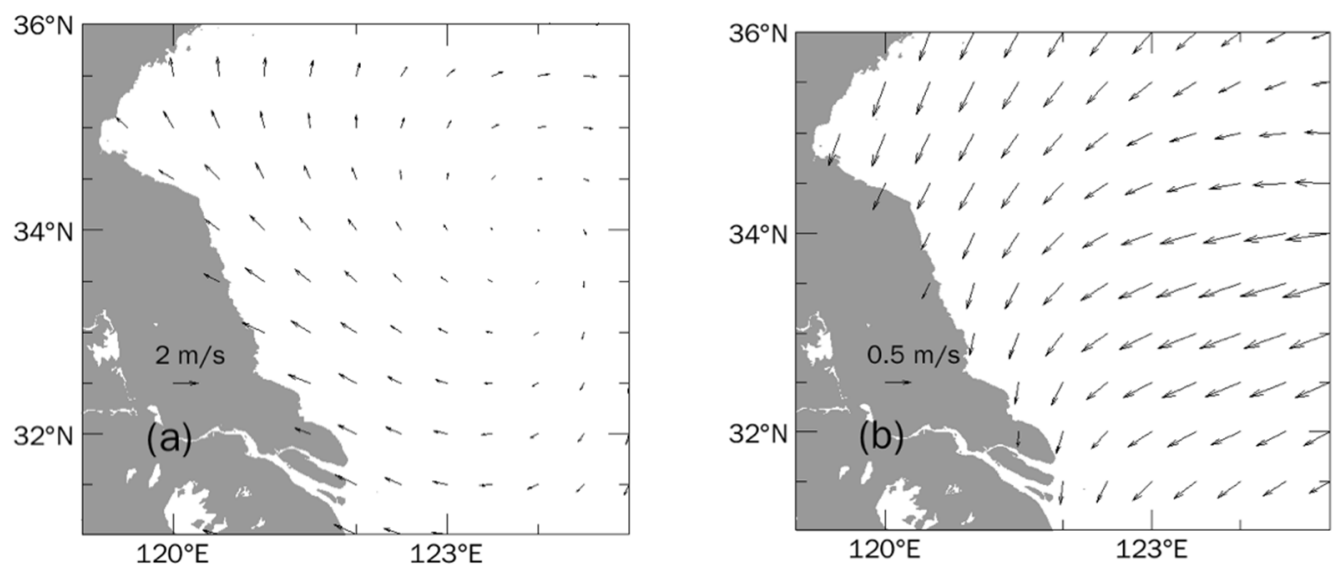

Figure 9. (a) Climatological spring wind distribution and (b) wind anomaly in the spring of 2021 at $10 \mathrm{~m}$ above the southwestern Yellow Sea.

Altogether, these results suggest that the nutrient contents from the Changjiang River were increased in the winter 2020-2021 and spring 2021 due to the increase of discharges. Additionally, the southerly wind stress anomaly during winter 2020-2021 also favored the upwind transport of Changjiang water. According to the tracer content, overall, the remaining freshwater coming from the Changjiang River, which persisted in the upper layer of $32-35^{\circ} \mathrm{N}, 119-122^{\circ} \mathrm{E}$ region during spring 2021 (April, May, June), exceeded the climatological value by nearly $20 \%$. At the same time, the stronger easterly wind 
component during spring of 2021 was conducive to the landing of Ulva prolifera along the Lunan coast. It should be pointed out that these experiments did not consider the nutrient concentration from Changjiang River in the individual years. Further quantitative investigations remain to be conducted in the future.

\section{Concluding Remarks}

The most massive outbreak on record of the Ulva prolifera green tides in the southwestern Yellow Sea occurred in summer of 2021. The environmental factors were investigated based on observations and simulations.

The results suggested that the enhanced discharges of the Changjiang River and the southerly wind stress anomaly in winter 2020-2021 were crucial for the outbreak of the Ulva prolifera green tides in the southwestern Yellow Sea, which could remarkably contribute to the nutrient enrichment off the Subei coast. The remaining freshwater coming from the Changjiang River, which persisted on the coast of Subei in the spring 2021, exceeded the climatological value by nearly $20 \%$. We demonstrated that these large amounts of nutrient inputs, as an effective supplement, were the reason the green tides sharply emerged as an extensive outbreak in 2021. Subsequently, the strong easterly wind anomaly during spring of 2021 led to shoreward transport, which was helpful for the large number of Ulva prolifera to land off the Lunan coast.

Author Contributions: Conceptualization, B.W.; Research approach, B.W.; Data analysis and writing, B.W. and L.W.; Figures, L.W.; Project administration, B.W. All authors have read and agreed to the published version of the manuscript.

Funding: This work was supported by the National Key Research and Development Project (2018YFD0900906), the Fundamental Research Funds for the Central Universities (B210203027), and National Natural Science Foundation of China (Project 41706023).

Institutional Review Board Statement: Not applicable.

Informed Consent Statement: Not applicable.

Data Availability Statement: MGDSSTs data were provided by the Japan Meteorological Agency, http://ds.data.jma.go.jp/gmd/goos/data/pub/JMA-product/ (accessed on 10 October 2021). ERA5 reanalysis meteorological forces and C3S sea level gridded data were provided by the European Centre for Medium-Range Weather Forecasts, https:/ / www.ecmwf.int/en/forecasts/datasets (accessed on 10 October 2021). The data of Changjiang River Discharge were provided by the Chinese River Sediment Bulletin.

Acknowledgments: The authors thank Zhixin Zhang of the First Institute of Oceanography, Ministry of Natural Resources, for providing the measured isohaline data. The authors also thank the editors and anonymous reviewers for their work on this paper.

Conflicts of Interest: The authors declare no conflict of interest.

\section{References}

1. Yuan, D.; Zhu, J.; Li, C.; Hu, D. Cross-shelf circulation in the Yellow and East China Seas indicated by MODIS satellite observations. J. Mar. Syst. 2008, 70, 134-149. [CrossRef]

2. Hu, C.; He, M.X. Origin and offshore extent of floating algae in Olympic sailing area. Eos Trans. AGU 2008, 89, 302-303. [CrossRef]

3. Qiao, F.; Lü, X. Coastal upwelling in the South China Sea. In Satellite Remote Sensing of South China Sea; Liu, A.K., Ho, C.R., Liu, C.T., Eds.; Tingmao Publish Company: Taipei, Taiwan, 2008; pp. 135-158.

4. Liu, D.; Keesing, J.K.; Dong, Z.; Zhen, Y.; Di, B.; Shi, Y.; Fearns, P.; Shi, P. Recurrence of the world's largest green-tide in 2009 in Yellow Sea, China: Porphyra yezoensis aquaculture rafts confirmed as nursery for macroalgal blooms-ScienceDirect. Mar. Pollut. Bull. 2010, 60, 1423-1432. [CrossRef]

5. Taylor, R.; Fletcher, R.L.; Raven, J.A. Preliminary studies on the growth of selected 'green tide' algae in laboratory culture: Effects of irradiance temperature, salinity and nutrients on growth rate. Bot. Mar. 2001, 4, 327-336. [CrossRef]

6. Zhang, X.; Wang, Z.; Li, R.; Li, Y.; Wang, X. Microscopic observation on population growth and reproduction of Eltrolnorphra prolifera under different temperature and salinity. Adv. Mar. Sci. 2012, 30, 276283.

7. Yuan, K.; Hong, C.; Ding, Y.; Song, X. Analysis of the seasonal and inter-annual changes of environmental factors in Enteromorpha prolifera green tide outbreak in the Yellow Sea. J. Guangxi Acad. Sci. 2018, 34, 204-209. 
8. Wu, T.; Zhao, L.; Liu, H.; Wang, T.; Han, X.R.; Shi, X.Y. Preliminary study on the influence of Enteromorpha prolifera on nutrients. Mar. Environ. Sci. 2013, 32, 347-352. (In Chinese)

9. Li, H.M.; Tang, H.J.; Shi, X.Y.; Zhang, C.S.; Wang, X.L. Increased nutrient loads from the Changjiang (Yangtze) River have led to increased harmful algal blooms. Harmful Algae 2014, 39, 92-101. [CrossRef]

10. Wang, J.; Yu, Z.; Wei, Q.; Yang, F.; Dong, M.; Li, D.; Gao, Z.; Yao, Q. Distributions of nutrients in the southwestern yellow sea in spring and summer of 2017 and their relationship with Ulva prolifera outbreaks. Oceanol. Limnol. Sin. 2018, 49, 1045-1053. (In Chinese)

11. Zhang, H.; Liu, K.; Su, R.; Shi, X.; Pei, S.; Wang, X.; Wang, G.; Wang, S. Study on the coupling relationship between the development of Ulva prolifera green tide and nutrients in the southern Yellow Sea in 2018. Haiyang Xuebao 2020, 42, 30-39. (In Chinese) [CrossRef]

12. Chen, Y.; Song, D.; Li, K.; Gu, L.; Wei, A.; Wang, X. Hydro-biogeochemical modeling of the early-stage outbreak of green tide (Ulva prolifera) driven by land-based nutrient loads in the Jiangsu coast. Mar. Pollut. Bull. 2020, 153, 111028. [CrossRef]

13. Wang, C.; Jiao, X.; Zhang, Y.; Zhang, L.; Xu, H. A light-limited growth model considering the nutrient effect for improved understanding and prevention of macroalgae bloom. Environ. Sci. Pollut. Res. 2020, 27, 1-9. [CrossRef]

14. Sun, K.; Ren, J.S.; Bai, T.; Zhang, J.; Liu, Q.; Wu, W.; Zhao, Y.; Liu, Y. A dynamic growth model of Ulva prolifera: Application in quantifying the biomass of green tides in the Yellow Sea, China. Ecol. Model. 2020, 428, 109072. [CrossRef]

15. Li, H.M.; Zhang, C.S.; Han, X.R.; Shi, X.Y. Changes in concentrations of oxygen, dissolved nitrogen, phosphate, and silicate in the southern yellow sea, 1980-2012: Sources and seaward gradients. Estuar. Coast. Shelf Sci. 2015, 163, 44-55. [CrossRef]

16. Zhang, Y.; He, P.; Li, H.; Li, G.; Liu, J.; Jiao, F.; Zhang, J.; Huo, Y.; Shi, X.; Su, R.; et al. Ulva prolifera green tide outbreaks and their environmental impact in the Yellow Sea, China. Neurosurgery 2019, 4, 825-838. [CrossRef]

17. Gong, N.; Shao, K.; Shen, K.; Gu, Y.; Ye, J.; Hu, C.; Shen, L.; Chen, Y.; Li, D.; Fan, J. Chemical control of overwintering green algae to mitigate green tide in the Yellow Sea. Mar. Pollut. Bull. 2021, 168, 112424. [CrossRef] [PubMed]

18. Luo, Q.J.; Yan, X.J.; Xu, S.L.; Xu, J.L.; Zhou, C.X.; Ma, B.; Yang, R.; Pei, L.Q. Method for Acid Treatment and Treatment of Green Algae and Infected Cells during Porphyra Haitanensis Cultivation. Chinese Patent CN 101822271B, 21 November 2012. (In Chinese)

19. Zhang, Z.X.; Guo, J.S.; Qiao, F.L.; Liu, Y.Y.; Guo, B.H. Whereabouts and freshwater origination of the Subei coastal water. Oceano Logia Limnol. Sin. 2016, 47, 527-532. (In Chinese)

20. Hirose, N.; Lee, H.C.; Yoon, J.H. Surface heat flux in the East China Sea and the Yellow Sea. J. Phys. Oceanogr. 1999, 29, 401-417. [CrossRef]

21. Matsumoto, K.; Takanezawa, T.; Ooe, M. Ocean tide models developed by assimilating TOPEX/POSEIDON altimeter data into hydrodynamical model: A global model and a regional model around Japan. J. Oceanogr. 2000, 56, 567-581. [CrossRef]

22. Kondo, J. Air-sea bulk transfer coefficients in diabetic conditions. Bound. Layer Meteor. 1975, 9, 91-112. [CrossRef]

23. Paulson, C.A.; Simpson, J.J. Irradiance measurements in the upper ocean. J. Phys. Oceanogr. 1977, 7, 952-956. [CrossRef]

24. Yang, H. A Research on Sustainable Development Strategic Option of Jiangsu Coast Beaches Resources. Ph.D. Thesis, China University of Geosciences, Beijing, China, 2012. (In Chinese)

25. Wang, B.; Hirose, N.; Moon, J.-H.; Yuan, D. Difference between the Lagrangian trajectories and Eulerian residual velocity fields in the southwestern Yellow Sea. Ocean Dyn. 2013, 63, 565-576. [CrossRef]

26. Wu, H.; Gu, J.; Zhu, P. Winter Counter-Wind Transport in the Inner Southwestern Yellow Sea. J. Geophys. Res. Ocean. 2018, 123, 411-436. [CrossRef]

27. Wei, Q.; Wang, B.; Fu, M.; Sun, J.; Yao, Q.; Xin, M.; Yu, Z. Spatiotemporal variability of physical-biogeochemical processes and intrinsic correlations in the semi-enclosed South Yellow Sea. Acta Oceanol. Sin. 2020, 39, 11-26. [CrossRef] 